\title{
Evaluation of Annual Allowable Cut (AAC) Determination of Teak Forest Plantations in Perum Perhutani, Indonesia
}

\author{
Rohman $^{1 *}$, Sofyan P. Warsito ${ }^{1}$, Nunuk Supriyatno ${ }^{1}$, Ris Hadi Purwanto ${ }^{1}$, Catur Atmaji ${ }^{2}$ \\ ${ }^{1}$ Faculty of Forestry, Gadjah Mada University, Bulaksumur, Yogyakarta, Indonesia 55281 \\ ${ }^{2}$ Faculty of Mathematics and Natural Sciences, Gadjah Mada University, Bulaksumur, Yogyakarta, Indonesia 55281
}

Received October 8, 2014/Accepted December 26, 2014

\begin{abstract}
The degradation of teak forest plantations in Java that are managed by Perum Perhutani (PP) continues to happen, and this is caused by some risk factors such as illegal logging, grazing, forest fire, and encroachment. However, these risk factors have not been considered by PP notably in annual allowable cut (AAC) determination of yield regulation. Therefore, the AAC value could be overestimated. The research was aimed at evaluating the method of $A A C$ determination and proposing an alternative method that considers the risk factors. This research was conducted with a series of data analysis approach from the data on five planning periods. The research result showed that forest damage occurs in varied situations. On average, the rate of deforestation accounted for $0.8 \%$ per annum. The calculation of $A A C$ by considering the rate of damage risk in normal condition approximately made up $70.8 \%$. Thus, compared to another method without considering damage risk rate, overestimation constituted $29.2 \%$. In brief, this had an impact on the decline of timber stock.
\end{abstract}

Keywords: teakforest plantation, Perum Perhutani, casualty per cent, AAC

*Correspondence author, email: rohman_fkt@ugm.ac.id,tel.:+62-813-28122428

\section{Introduction}

The conception of the fully regulated forest, in the classical timber management, scheduling addressed the questions of how many areas and how much volume to cut. Over the years of forest history, several methods for determining the cut were developed in various parts of the world (Davis et al. 2001). These methods are formulated to achieve a harvest schedule that exhibits nondeclining yield or below long-term sustained yield capacity. Sustained yield in this context dealt with achieving a permanence of timber resources through limiting harvesting to a level that could be maintained over time.

Luckert and Williamson (2005) explain that sustained yield principles are not essential. Deten (2011) states that it is not possible for forest planning experts to adequately integrate the manifold and intangible relevant factors from nature (e.g. climate and its change, natural hazards, changing site factors) and society (e.g. global market development, social changes, rearrangements of the political environment) into forest management plans which sustainably shape forests. van Gardingen et al. (2006) recognizes that yield regulation should be adaptable to the different contexts (social, ecological, environmental, and economic) and the variety of objectives for forest management. However, Elbakidze et al. (2013) state that the concept of sustained yield in forestry only could disappear as a separate concept, and sustainable wood production will be just one criterion to be considered in Sustained Forest Management along with other criteria.
Regulation of the yield requires (a) a calculation of the amount of the yield should be, (b) an apportionment of that yield to thinnings and final fellings, and (c) the construction of a cutting plan which determines the identity of stands to be felled or thinned and the time of their felling or thinning (Recknagel 1917; Osmaston 1968). Seydack et al. (1995) add that forest sustainable regulation ensures how to determine the optimal residual growing stock. Warsito (2010) mentions that the activity of harvesting has the biggest impact on forest stand sustainability, so the forest management should be planned from harvesting regulation.

Teak forest in Java-Indonesia has been managed for more than 12 centuries, starting from the era of the Javanese Kingdoms, during the era of Dutch colonial, and until the present time under the management of Perum Perhutani (PP, a state-owned forest entreprise) (Simon 2010). Almost 61\% of state forest areas in Java have been established as production forests (MoF 2008), approximately $60 \%$ of which are managed as teak plantations (Perhutani 2011).

Since the 60 s, teak forests in Java that are managed by PP have been experiencing a stand quality decline (Simon 2001) due to the various of forest disturbances (i.e. illegal logging, forest fire, grazing, fuelwood collection, and encroachment). Forest disturbances, which accelerated during the period of economic crisis (1998-1999), have caused severe destruction that has drastically changed the age structure of teak plantations (Tiryana et al. 2011). In the last two decades, the forest area depletion characterized by the forest stand structure which is dominated by young stands (1-20 
years), bare land, and other types of unproductive land. In 2011, the young stand of teak forests area accounted for 452,000 ha or $80 \%$ of the productive forests area (Perhutani 2011). A high rate of unplanned harvesting, especially to the remaining stands in illegal-logging areas brought unbalanced distribution of the teak growing stock and it gives a bad sign for unsustainable harvest in the future (Ichwandi et al. 2009). Although the effect of forest disturbances on teak plantation is obvious, the potential risk of stand destruction is still ignored in the current forest management planning, especially when PP determines the annual allowable cut (AAC) (Tiryana et al. 2011).

The risk of the forest damage must be integrated in longterm forest management. Integrating risk into long-term forest management means applying the entire risk management process to decisions made (Hanewinkel et al. 2011). Modeling the risk of forest damage has done to damage caused by natural hazards, for damage caused by illegal logging is relatively rare. Modeling of forest destruction (mainly due to illegal logging) in teak plantations have been done with survival analysis approach (Tiryana et al. 2011), but it has not been used for the determination of AAC. Another risk consideration focus on how to reduce the volume of harvested timber based on predicted risk (Leech 2002).

Currently, AAC in PP is determined by using Burn method, which estimates the growing stock volume at average cutting time (ACT) (Soeranggajiwa 1978). ACT is the time indicating a combination of weighted average age, determined based on forest inventory, and half of the rotation period. The method is regulated in the Director-General of Forestry Decree Number 143/KPTS/DJ/1974 (Ministry of Agriculture 1974), known as '74 Instruction. The regulation has been revised by the Ministry of Forestry Regulation Number P.60/Menhut-II/2011, but the determination of AAC remains using the same method as before (Perhutani 2013).

One outcome of forest inventory is the structure of age classes which describes the actual standing stock. Teak forest age classes in the PP has a 10-year interval, for example, age class I $\left(A C_{I}\right)$ consists of stand aged between 1-10 years old, age class II $\left(\mathrm{AC}_{\mathrm{II}}\right)$ aged 11-20 years old, and so on. A forest consisting of $A C_{\mathrm{I}}$ with an area $L_{I}$ and the weighted average age of the $\mathrm{U}_{\mathrm{I}}, A C_{I I}$ with an area $L_{I I}$ and the weighted average age of $U_{I I}$, and so on until the $A C_{n}$ with an area $L_{n}$ and the average age of the $U_{n}$, managed with rotation of $R$ years, will have an ACT as explained in Equation [1].

$$
A C T=\frac{\sum_{i=I}^{n} L i \cdot U i}{\sum_{i=I}^{n} L i}+\frac{1}{2} R
$$

Estimation of the growing stock for AAC determination is calculated at the ACT (not the actual age) by using the Wolff von Wulfing (WvW) yield table of teak stands (Departemen Pertanian 1974). The estimated volume of $A_{I}$ calculated by the formula, $\mathrm{V}_{\mathrm{I}}=\mathrm{L}_{\mathrm{I}} \times \mathrm{V}_{\mathrm{ACT}}, \mathrm{V}_{\mathrm{II}}=\mathrm{L}_{\mathrm{II}} \times \mathrm{V}_{\mathrm{ACT}}$, and so on up to $\mathrm{V}_{\mathrm{n}}=\mathrm{L}_{\mathrm{n}} \times \mathrm{V}_{\mathrm{ACT}}$. $\mathrm{V}_{\mathrm{ACT}}$. $\quad V_{A C T}$ is the volume on the $\mathrm{WvW}$ table at the age of ACT multiplied by basal area density index (BDI). BDI is defined as a ratio between the current basal area (from the forest inventory) and the normal basal area (from the $\mathrm{WvW}$ table). The total volume of all the forest area is calculated by Equation [2] and the AAC determined by the Equation [3].

$$
\begin{aligned}
& V t o t=\sum_{i=I}^{n} V i \\
& A A C=\frac{V t o t}{R}
\end{aligned}
$$

This approach is assumed that all stands are determined in the future (ACT) and the planner assumes there will be no risk or stand failure damaging the stand up to ACT or the rotation age. Hardjosoediro (1974) stated that the estimated volume at the end of the final cutting could be illustrated as an "imagined value". For instance, a stand aged 5 years old and will be cut at age 50 years old, will grow up for 45 years without any reducing areas. In fact, the forest stands are dynamic and most of them are vulnerable due to the various of disturbances (Rohman 2008).

To deal with this weakness, in 1865 Brandis considered the dynamic risk by implementing his method in natural teak forests in Pegu, Burma (Osmaston 1968). Since 1856, teak forests management in Burma adopted a selective cutting system known as Myanmar Selection System (MSS) (Mon et al. 2012). The method requires a knowledge of three attributes of the growing stock, one of this is the casualty per cent (CPC) of each size-class. CPC is defined as the percentage of the stand number of each class that fails to reach the diameter of exploitable size (Osmaston 1968). According to this method, trees with small diameters are exemplified as having a CPC of $75 \%$, so that only $25 \%$ of the trees would be able to reach the exploitable size.

The CPC is effectively used for the belief that not all of trees would be able to reach the exploitable size. This also happens in the teak plantations of PP that not all of the young stands can reach the age of final cutting. The research was aimed at evaluating the method of AAC determination and proposing the CPC as an alternative method that considers the risk factors.

\section{Methods}

This research was conducted in PP which manages almost all of the state forests (production forests and protected forests) in Java. The total of PP working area covers an area of approximately 2.4 million hectares which divided into 3 division, namely Central Java division (630,719 ha), East Java Division (1,136,479 ha), and West Java and Banten Division (659,007 ha) (Perhutani 2011). Each division is divided into Forest Management Unit (FMU) as the unit of management at site level. Central Java Disvision is a region of the earliest established the FMU, which began in 1898 (Simon 2010). Central Java Division divided into 20 FMU and as many as 14 FMU is managed with the main products of teak wood. Randublatung FMU is one of the FMU that produce teak which well-managed. This is indicated by obtaining a certificate of Sustainable Forest Management (SFM) with Forest Stewardship Council (FSC) standards in 2012.

The total area of Randublatung FMU is 32,464.1 ha, divided into 6 planning units called Bagian Hutan $(\mathrm{BH})$ such 
as BH Randublatung (5,110.1 ha), BH Doplang (5,801.5 ha), BH Bekutuk (4,818.5 ha), BH Ngliron (6,235.8 ha), BH Banyuurip (5,044,3 ha), and BH Banglean (4,889.0 ha). All of the forest areas in Randublatung FMU are managed for teak production. The AAC determination in PP was conducted in each $\mathrm{BH}$, therefore, the research data was analyzed in every BH. The attached example of analysis process was from $\mathrm{BH}$ Banyuurip, whereas for the other $\mathrm{BH}$ in Randublatung FMU, only the result was presented.

Data collection and processing The material of this research is the data of the forest area over planning periods. The data were taken from the forest inventory data, which came from the periodic forest inventories (10-year measurement cycle). The forest inventory data contained reliable information on teak stands in each sub-compartment, e.g. the size of stands (in hectares), stand variables (e.g. top height, basal areal density index, age), and a brief description of stand conditions (e.g. classification into productive or unproductive stands). The data used by PP to develop a 10year working plan for teak plantations. The data over five planning periods comprising 1973-1982, 1983-1992, 1993-2002, 2003-2012, and 2013-2022 were used in this research. The data were analysed by the following steps:

1 Calculating the forest damage from age of $t$ and $t+10$ years $(1<t<60)$ for cycle of 60 years. This was analysed by implementing Equation [4] (Tiryana et al. 2011) :

$d_{i}=r_{i t} c_{(i+1)}$

where $d_{i}$ is damaged stands between age $t$ to $t+10$ years or demaged stands of $\left(\mathrm{AC}_{i}\right)$ in ha, $r_{i t}$ represents forest stand area at the age of $i$ on $t$ years, $t$ is the beginning year of a planning period (for instance 1973-1983), and $c_{(i+1)}$ represent surviving stand ( area of $\mathrm{AC}_{(i+1)}$ at the year of $t+10)$.

2 Calculating the percentage of forest damage rate $\left(x_{i}\right)$ of $\mathrm{AC}_{\mathrm{i}}$ to the area in the beginning of planning period. There were two periods analysed, i.e. the period without the massive illegal logging (1973-1992) and the period of 1993-2012 with the massive illegal logging cases.

3 Calculating the $\mathrm{CPC}$ of the $\mathrm{AC}_{\mathrm{i}}$ in order to reach the rotation age based on the forest damage rate in each age class. In brief, if the damage rate of $\mathrm{AC}_{\mathrm{i}}$ to $\mathrm{AC}_{(\mathrm{i}+1)}$ (expressed in $x_{i} \%$ ), the $\mathrm{CPC}(Y \%)$ from $\mathrm{AC}_{\mathrm{i}}$ to $\mathrm{AC}_{\mathrm{n}}$ can be predicted with Equation [5] :

$Y_{i \%}=1-\prod_{i=i}^{n+1}\left(1-X_{i} \%\right)$

where $n$ is $\mathrm{AC}_{\mathrm{VII}}$ (rotation of 60 years).

4 Calculating AAC determination by involving the CPC value from point 3 . In short, if there is $\mathrm{AC} i$ with area of $A i$ ha, then the forest area that could be used in AAC determination $\left(A_{i}\right)$ is:

$\dot{A_{i}}=A_{i}-A_{i} \cdot Y_{i} \%$

\section{Results and Discussion}

The dinamic of productive forest area The productive forest area in this paper has been explained by PP terminology (Ministry of Agriculture 1974) for AAC determination such as maturity (masak tebang or MT), low increment (miskin riap or MR), and age-class (AC). The definitions of those stand classes are based on the age as well as the basal area density index (BDI). $\mathrm{AC}_{1}$ is a group of forests stand of $1-10$ years old with BDI of $\geq 0.6$. The width of the productive forest areas in Randublatung FMU undergo changes due to the increase of age. Overall, the productive forest area from period $t$ to period $t+1$ undergoes a decreasing trend as shown in Table 1.

As mentioned above, in this paper the calculation process just described for BH Banyuurip. The dynamic of productive forest area in $\mathrm{BH}$ Banyuurip are presented in Table 2. As in FMU level, BH Banyuurip also experienced the productive forest area decline from one period to another

Table 1 The productive forest area in Randublatung FMU during 5 planning periods

\begin{tabular}{|c|c|c|c|c|c|}
\hline \multirow{2}{*}{$\begin{array}{l}\text { Stand-age } \\
\text { classes }\end{array}$} & \multicolumn{5}{|c|}{ Productive forest area at the begining of planning period (ha) } \\
\hline & $1973-1982$ & $1983-1992$ & $1993-2002$ & $2003-2012$ & $2013-2022$ \\
\hline$-\mathrm{AC}_{\mathrm{I}}$ & 5,269 & 4,412 & 3,962 & 7,369 & 9,352 \\
\hline$-\mathrm{AC}_{\mathrm{II}}$ & 5,197 & 5,038 & 4,452 & 3,611 & 4,247 \\
\hline$-\mathrm{AC}_{\mathrm{III}}$ & 2,846 & 4,867 & 4,484 & 2,458 & 2,736 \\
\hline$-\mathrm{AC}_{\mathrm{IV}}$ & 2,776 & 2,732 & 4,611 & 1,983 & 1,724 \\
\hline$-\mathrm{AC}_{\mathrm{V}}$ & 3,280 & 2,141 & 2,353 & 2,162 & 1,043 \\
\hline$-\mathrm{AC}_{\mathrm{VI}}$ & 2,371 & 2,985 & 2,071 & 956 & 1,635 \\
\hline$-\mathrm{AC}_{\mathrm{VII}}$ & 1,972 & 2,152 & 2,697 & 1,181 & 796 \\
\hline$-\mathrm{AC}_{\mathrm{VIII}}$ & 915 & 1,736 & 1,893 & 1,189 & 663 \\
\hline$-\mathrm{AC}_{\mathrm{IX}}$ & 478 & 827 & 424 & 186 & - \\
\hline$-\mathrm{AC}_{\mathrm{X}}$ & 14 & 386 & - & 17 & - \\
\hline$-\mathrm{AC}_{\mathrm{XI}}$ & 44 & - & - & - & - \\
\hline - MT & - & 604 & 301 & 7 & 51 \\
\hline - MR & 4,848 & 1,763 & 1,410 & 1,061 & 640 \\
\hline Total & 30,010 & 29,641 & 28,658 & 22,179 & 22,887 \\
\hline
\end{tabular}


period. For instance, the area of $\mathrm{AC}_{\mathrm{I}}$ at the beginning of the planning period of 1973-1982 with 702.9 ha had been decreased to 666.8 ha at the beginning of the planning period of 1983-1992, and change to 537.0 ha at the beginning of the planning period of 1993-2002.

The rate of forest damage The rate of forest damage depicted the alteration from productive forest areas to unproductive forest areas during certain periods. Based on periodic forest inventory data (see Table 2), there are some stand-age classes which have area increase compared to the previous period. In the $\mathrm{AC}_{\mathrm{I}}$ for period of 1983-1992 has significant rise from 629.1 ha to 672.2 ha in the next period. This was due to the unproductive forest areas had been changed to the productive forest areas with in 10 years. However, these cases should be ignored, then the areas were considered have the same width as the previous period. Similarly, the depletion in productive forest area over of $\mathrm{AC}_{\mathrm{VII}}$ does not count as damage because the rotation of Randublatung FMU is 60 years, so that the depletion of productive forest area is likely to be caused by logging activities of PP. Unfortunately, comprehensive historical data on forest disturbances are not available, making it difficult to quantify and compare the amount and intensity of its disturbance agent (i.e. illegal logging, forest fire, grazing, fuelwood collection, and encroachment) for each period. However, for teak forests, generally the agent of disturbance for $\mathrm{AC}_{\mathrm{I}}$ are forest fire, grazing, and encroachment, while for another AC mostly caused by illegal logging.

By implementing Equation [4] and calculating in step (2), the rate of forest damage can be seen in Table 3. On average, the rate of forest damage in the period of 1973-1992 could not show a certain pattern. In general, the average of damage rate in BH Banyuurip in the period of 1973-1992 accounted for $10.7 \%$ annually. The highest damage rate in the period was in $\mathrm{AC}_{\mathrm{IV}}$ which made up $30.4 \%$. Further, in the period of 1993-2012, when the illegal logging massively occurred, the forest damage experienced a significant increase in every AC with an average rate of $2.1 \%$ per annum.

In the FMU level, the damage rate for the period of 1973-1992 constituted $8.2 \%$ in average per period or $0.8 \%$ per year, as well as in the period of 1993-2012 the trend had increased approximately $3.7 \%$ per year. By comparing it to Kebonharjo FMU (Tiryana et al. 2011), the damage rate

Table 2 The productive forest area in BH Banyuurip during 5 planning periods

\begin{tabular}{|c|c|c|c|c|c|}
\hline \multirow{2}{*}{$\begin{array}{l}\text { Stand-age } \\
\text { classes }\end{array}$} & \multicolumn{5}{|c|}{ Productive forest area at the beginning of planning period (ha) } \\
\hline & $1973-1982$ & $1983-1992$ & $1993-2002$ & $2003-2012$ & $2013-2022$ \\
\hline $\mathrm{AC}_{\mathrm{I}}$ & 702.9 & 629.1 & 836.7 & 854.6 & $1,078.0$ \\
\hline $\mathrm{AC}_{\mathrm{II}}$ & 821.8 & 666.8 & 672.2 & 763.2 & 585.1 \\
\hline $\mathrm{AC}_{\mathrm{III}}$ & 578.9 & 712.9 & 537.0 & 485.7 & 577.7 \\
\hline $\mathrm{AC}_{\mathrm{IV}}$ & 360.5 & 582.0 & 849.0 & 408.1 & 387.3 \\
\hline $\mathrm{AC}_{\mathrm{V}}$ & 571.0 & 227.4 & 441.0 & 631.7 & 287.0 \\
\hline $\mathrm{AC}_{\mathrm{VI}}$ & 283.0 & 526.4 & 289.9 & 217.9 & 562.8 \\
\hline $\mathrm{AC}_{\mathrm{VII}}$ & 656.0 & 261.5 & 452.0 & 184.5 & 216.3 \\
\hline $\mathrm{AC}_{\mathrm{VIII}}$ & 157.1 & 383.6 & 208.6 & 322.7 & 85.2 \\
\hline $\mathrm{AC}_{\mathrm{IX}}$ & - & 97.3 & 22.2 & - & - \\
\hline MT & - & - & 80.4 & - & 1.2 \\
\hline MR & 496.3 & 572.4 & 260.3 & 103.6 & 77.3 \\
\hline Total & $4,627.5$ & $4,659.3$ & $4,649.3$ & $3,972.0$ & $3,857.9$ \\
\hline
\end{tabular}

Table 3 The rate of forest damage in each period of $\mathrm{BH}$ Banyuurip

\begin{tabular}{|c|c|c|c|c|c|c|}
\hline \multirow{2}{*}{$\mathrm{AC}_{i}$ to $\mathrm{AC}(i+1)$} & \multicolumn{6}{|c|}{ Forest damage rate in $\mathrm{BH}$ Banyuurip per period (\%) } \\
\hline & $1973-1982$ & $1983-1992$ & $1993-2002$ & $2003-2012$ & $\begin{array}{c}\text { Average } \\
73-92\end{array}$ & $\begin{array}{c}\text { Average } \\
93-12 \\
\end{array}$ \\
\hline $\mathrm{AC}_{\text {I-II }}$ & 5.1 & - & 8.8 & 31.5 & 2.6 & 20.2 \\
\hline $\mathrm{AC}_{\mathrm{II}-\mathrm{III}}$ & 13.3 & 19.5 & 22.8 & 24.3 & 16.4 & 23.6 \\
\hline $\mathrm{AC}_{\text {III-IV }}$ & - & - & 24.0 & 20.3 & - & 22.1 \\
\hline $\mathrm{AC}_{\mathrm{IV}-\mathrm{V}}$ & 36.9 & 23.8 & 11.4 & 29.7 & 30.4 & 20.5 \\
\hline $\mathrm{AC}_{\mathrm{V}-\mathrm{VI}}$ & 7.8 & - & 50.6 & 10.9 & 3.9 & 30.7 \\
\hline $\mathrm{AC}_{\mathrm{VI}-\mathrm{VII}}$ & 7.6 & 14.1 & 18.9 & 0.7 & 10.9 & 9.8 \\
\hline Average & 11.8 & 9.6 & 22.7 & 19.6 & 10.7 & 21.2 \\
\hline
\end{tabular}


accounted for $2 \%$ for the period before the massive illegal logging cases and rose to $3.5 \%$ per year after the massive illegal logging cases. Those showed that the damage rates in both Randublatung FMU and Kebonharjo FMU were similar. FMU of Kebonharjo is an example of FMU in Central Java Division has obtained the certificate of SFM as Randublatung FMU. It shows that the forest damage has occurred in FMU which had been well-managed. Those rates were still above the maximum damage rate decided by PP for Randublatung FMU which made up $1 \%$ for improved condition (the same condition as the condition before the massive illegal logging cases) and $1.75 \%$ for pessimistic condition (Perhutani 2009).

The risk of forest damage over the cycle Based on the rate of forest damage as depicted in Table 4, by implementing Equation [5] the CPC could be obtained as is showed in Table 5. In 1973-1992, the CPC of $\mathrm{AC}_{\mathrm{I}}$ accounted for $51.4 \%$. The value showed that the productive forest area in $\mathrm{AC}_{\mathrm{I}}$ was predicted to be damaged at $51.4 \%$ to reach the age of final cutting. $\mathrm{AC}_{\mathrm{I}}$ has the greatest value of the $\mathrm{CPC}$ as an accumulation of damage from the $\mathrm{AC}_{\mathrm{I}}, \mathrm{AC}_{\mathrm{II}}$, and so on until the rotation age.

By implementing the similar procedure, there would be a CPC value for all $\mathrm{BH}$ in Randublatung FMU as mentioned in Table 6 for the periods of 1973-1992 (A) and 1993-2013 (B). The varied value of CPC showed the differences of the rate of forest damage in each $\mathrm{BH}$. As showen in Table 6, the risk of forest damage in Randublatung FMU underwent significant changes before and after the massive illegal logging cases. Before the event of the cases, $\mathrm{BH}$ Randublatung had the smallest damage rate, then increase a sharply after the case occured. Generally, BH Banglean and $\mathrm{BH}$ Banyuurip haved low damage rate, while $\mathrm{BH}$ Doplang underwent the most serious damage both before and after the cases.

Overall, when the condition improved as before the massive illegal logging, the $\mathrm{CPC}$ in $\mathrm{AC}_{\mathrm{I}}$ accounted for $46.4 \%$ which mean $53.6 \%$ of $\mathrm{AC}_{\mathrm{I}}$ was predicted to survive until the age of final cutting. This result had the same value as that of the survival analysis approach (Tiryana et al. 2011) for Kebonharjo FMU which mentioned that the survival probability before 1997 (before the massive illegal logging cases) made up 55\% for cycle of 60 years. On the other hand, if the damaged condition continued to happen as in the condition in the 1993-2013, there would be only about $11.5 \%$ of $\mathrm{AC}_{\mathrm{I}}$ that was predicted to survive until the end of rotation. The better condition as targeted by PP was that with only $1 \%$ of forest damage on average per year, it would result in a CPC as well as that was more or less like the condition before the period of 1993-2002.

AAC determination using the casualty per cent The CPC is used for area width correction in AAC calculation in PP.

Table 4 Forest damage rates in each period in Randublatung FMU

\begin{tabular}{|c|c|c|c|c|c|c|}
\hline \multirow{2}{*}{$\mathrm{AC}_{i}$ to $\mathrm{AC}_{(i+1)}$} & \multicolumn{6}{|c|}{ Forest damage rate in each period $(\%)$} \\
\hline & $1973-1982$ & $1983-1992$ & $1993-2002$ & $2003-2012$ & Average $73-92$ & Average $93-12$ \\
\hline $\mathrm{AC}_{\mathrm{I}-\mathrm{II}}$ & 4.4 & 0.0 & 8.9 & 42.4 & 2.2 & 25.6 \\
\hline $\mathrm{AC}_{\mathrm{II}-\mathrm{III}}$ & 6.4 & 11.0 & 44.3 & 24.2 & 8.7 & 34.3 \\
\hline $\mathrm{AC}_{\mathrm{IIII}-\mathrm{IV}}$ & 4.0 & 5.3 & 55.8 & 29.9 & 4.6 & 42.8 \\
\hline $\mathrm{AC}_{\mathrm{IV}-\mathrm{V}}$ & 22.9 & 13.9 & 53.1 & 47.4 & 18.4 & 50.3 \\
\hline $\mathrm{AC}_{\mathrm{V}-\mathrm{VI}}$ & 9.0 & 3.2 & 59.4 & 24.4 & 6.1 & 41.9 \\
\hline $\mathrm{AC}_{\mathrm{VI}-\mathrm{VII}}$ & 9.2 & 9.6 & 43.0 & 16.8 & 9.4 & 29.9 \\
\hline Average & 9.3 & 7.2 & 44.1 & 30.8 & 8.2 & 37.5 \\
\hline
\end{tabular}

Table 5 The Casualty Per Cent of each age-class in BH Banyuurip

\begin{tabular}{|c|c|c|c|c|c|}
\hline \multicolumn{3}{|c|}{$\begin{array}{l}\text { The rate of forest damage from } \mathrm{AC}_{\mathrm{i}} \text { to } \mathrm{AC}_{(\mathrm{i}+1)} \\
\qquad(\%)\end{array}$} & \multicolumn{3}{|c|}{$\begin{array}{l}\text { Casualty per cent } \mathrm{AC}_{\mathrm{i}} \text { to } \mathrm{AC}_{\mathrm{VII}} \\
\text { (cycle of } 60 \text { years) }(\%)\end{array}$} \\
\hline $\mathrm{AC}_{i}$ to $\mathrm{AC}_{(i+1)}$ & Average $73-92$ & Average 93-12 & ACi to $\mathrm{AC}_{\mathrm{VII}}$ & Average $73-92$ & Average 93-12 \\
\hline $\mathrm{AC}_{\mathrm{I}-\mathrm{II}}$ & 2.2 & 25.6 & $\mathrm{AC}_{\mathrm{I}^{-} \mathrm{VII}}$ & 51.4 & 76.4 \\
\hline $\mathrm{AC}_{\text {II }- \text { III }}$ & 8.7 & 34.3 & $\mathrm{AC}_{\text {II-VII }}$ & 50.1 & 70.4 \\
\hline $\mathrm{AC}_{\text {III-IV }}$ & 4.6 & 42.8 & $\mathrm{AC}_{\text {III-VII }}$ & 40.4 & 61.3 \\
\hline $\mathrm{AC}_{\mathrm{IV}-\mathrm{V}}$ & 18.4 & 50.3 & $\mathrm{AC}_{\mathrm{IV}-\mathrm{VII}}$ & 40.4 & 50.4 \\
\hline $\mathrm{AC}_{\mathrm{V}-\mathrm{VI}}$ & 6.1 & 41.9 & $\mathrm{AC}_{\mathrm{V}-\mathrm{VII}}$ & 14.4 & 37.5 \\
\hline $\mathrm{AC}_{\mathrm{VI}-\mathrm{VII}}$ & 9.4 & 29.9 & $\mathrm{AC}_{\mathrm{VI}-\mathrm{VII}}$ & 10.9 & 9.8 \\
\hline
\end{tabular}

Note: The calculation of the $\mathrm{CPC}$ to the $\mathrm{AC}_{\mathrm{VII}}$ as a limit that the stand can be harvested when it is fulfilled 60 years. 
Table 6 The casualty per cent of each BH in Randublatung FMU

\begin{tabular}{|c|c|c|c|c|c|c|c|c|c|c|c|c|c|c|}
\hline \multirow{3}{*}{$\mathrm{AC} i$ to $\mathrm{AC}_{\mathrm{VII}}$} & \multicolumn{14}{|c|}{ Casualty per cent $\mathrm{AC} i$ to $\mathrm{AC}_{\mathrm{VII}}$ (cycle of 60 years) per $\mathrm{BH}(\%)$} \\
\hline & \multicolumn{2}{|c|}{ Banyuurip } & \multicolumn{2}{|c|}{ Randublatung } & \multicolumn{2}{|c|}{ Ngliron } & \multicolumn{2}{|c|}{ Doplang } & \multicolumn{2}{|c|}{ Bekutuk } & \multicolumn{2}{|c|}{ Banglean } & \multicolumn{2}{|c|}{ FMU } \\
\hline & A & B & A & B & A & B & A & B & A & B & A & B & A & B \\
\hline $\mathrm{AC}_{\mathrm{I}-\mathrm{VII}}$ & 51.4 & 76.4 & 23.4 & 99.6 & 42.2 & 92.4 & 76.3 & 99.7 & 38.7 & 97.2 & 40.5 & 76.8 & 46.4 & 88.5 \\
\hline $\mathrm{AC}_{\text {II-VII }}$ & 50.1 & 70.4 & 22.2 & 99.5 & 39.5 & 91.1 & 73.7 & 99.5 & 38.5 & 96.1 & 40.5 & 70.6 & 44.6 & 86.1 \\
\hline $\mathrm{AC}_{\mathrm{III}-\mathrm{VII}}$ & 40.4 & 61.3 & 14.6 & 99.0 & 34.1 & 87.8 & 69.2 & 98.8 & 35.6 & 94.5 & 40.2 & 63.3 & 39.7 & 82.4 \\
\hline $\mathrm{AC}_{\mathrm{IV}-\mathrm{VII}}$ & 40.4 & 50.4 & 14.4 & 98.2 & 29.6 & 81.3 & 55.4 & 94.3 & 33.2 & 89.5 & 38.4 & 45.5 & 35.0 & 75.2 \\
\hline $\mathrm{AC}_{\mathrm{V}-\mathrm{VII}}$ & 14.4 & 37.5 & 6.6 & 94.5 & 20.3 & 59.6 & 35.7 & 79.7 & 20.1 & 67.7 & 22.3 & 22.8 & 20.6 & 58.4 \\
\hline $\mathrm{AC}_{\mathrm{VI}-\mathrm{VII}}$ & 10.9 & 9.8 & 6.6 & 80.6 & 1.7 & 25.9 & 28.1 & 60.4 & 14.6 & 31.9 & 9.7 & 4.3 & 11.9 & 35.2 \\
\hline
\end{tabular}

Table 7 The AAC determination by considering casualty per cent in BH Banyuurip

\begin{tabular}{|c|c|c|c|c|c|}
\hline \multirow{2}{*}{$\mathrm{AC}$} & \multicolumn{2}{|c|}{ '74 Instruction ** } & \multicolumn{3}{|c|}{ Casualty per cent } \\
\hline & Initial of areas (ha) & Volume at $\mathrm{ACT}\left(\mathrm{m}^{3}\right)$ & Casualty per cent & Corrected areas (ha) & $\begin{array}{c}\text { Volume at the rotation } \\
\text { age }\left(\mathrm{m}^{3}\right)\end{array}$ \\
\hline 1 & 2 & 3 & 4 & 5 & 6 \\
\hline MR & 104 & 6,630 & $0 \%$ & 104 & 6,630 \\
\hline $\mathrm{AC}_{\mathrm{VIII}}$ & 323 & 47,760 & $0 \%$ & 323 & 47,760 \\
\hline $\mathrm{AC}_{\mathrm{VII}}$ & 185 & 25,830 & $0 \%$ & 185 & 25,830 \\
\hline $\mathrm{AC}_{\mathrm{VI}}$ & 218 & 23,751 & $10.9 \%$ & 194 & 21,162 \\
\hline $\mathrm{AC}_{\mathrm{V}}$ & 632 & 72,014 & $14.4 \%$ & 541 & 61,644 \\
\hline $\mathrm{AC}_{\mathrm{IV}}$ & 408 & 59,583 & $40.4 \%$ & 243 & 35,511 \\
\hline $\mathrm{AC}_{\text {III }}$ & 486 & 57,313 & $40.4 \%$ & 289 & 34,159 \\
\hline $\mathrm{AC}_{\mathrm{II}}$ & 763 & 94,637 & $50.1 \%$ & 381 & 47,224 \\
\hline $\mathrm{AC}_{\mathrm{I}}$ & 855 & 107,680 & $51.4 \%$ & 415 & 52,332 \\
\hline Total & 3.972 & 495,198 & & 2,675 & 332,253 \\
\hline $\mathrm{AAC}$ & $66.2{\text { ha } y r^{-1}}^{-1}$ & $8,253 \mathrm{~m}^{3} \mathrm{yr}^{-1}$ & & 44.6 ha yr $^{-1}$ & $5.538 \mathrm{~m}^{3} \mathrm{yr}^{-1}$ \\
\hline
\end{tabular}

** Source: Working Plan of Randublatung FMU, planning period of 2003-2012

The '74 Instruction assumed that all of timber stands as the result of forest inventory would survive until the age of final cutting. The CPC evaluated this area with different perception. Thus, there were some part of the productive forest areas that would be decreased until the age of final cutting. Table 7 shows the comparison of the results of ' 74 instruction calculation and the CPC method.

AAC value by considering $\mathrm{CPC}$ in $\mathrm{BH}$ Banyuurip accounted for $5,538 \mathrm{~m}^{3} /$ year or $67 \%$ of ACC without CPC which made up $8,253 \mathrm{~m}^{3}$ year $^{-1}$. It could be assumed that there was overestimation of $33 \%$ caused by forest damage. However, if the AAC of $8,253 \mathrm{~m}^{3}$ year ${ }^{-1}$ or $82,530 \mathrm{~m}^{3}$ for 10 years should be applied, then on the first 10 years the class $\mathrm{MR}, \mathrm{ACV}_{\mathrm{III}}, \mathrm{AC}_{\mathrm{VII}}$, and a half of $\mathrm{AC}_{\mathrm{IV}}$ could be harvested (see column 3 in Table 7). In the next 10 years, only a half of $A_{V I}$ could be harvested. Thus, there would be a chance to harvest below the cycle or the standard of cycle should be downgraded. Overall, in Randublatung FMU, with the optimistic condition, the result of AAC determination with CPC was $70.8 \%$ when compared to ' 74 instruction. The more detailed results of the AAC in each $\mathrm{BH}$ are depicted in Table 8 .

In many cases, teak forests in Java experience many risks that damage their stand attributes even though the forest areas are in secure condition (less conflict). The damage of forest due to the various disturbances in Randublatung FMU, for example, on average is $0.8 \%$ per year, in Purwodadi FMU is $2 \%$ per year (Rohman 2008), and in Kebonharjo FMU is $2 \%$ per year (Tiryana et al. 2011). PP also recognizes this by setting the number of damage about $1 \%$ per year for such conditions before the massive illegal logging case (Perhutani 2009). Although this risk continues to occur and degrades the stand quality and productive areas, the planner has never considered this risk in determining AAC. Revised 
Table 8 The comparison of AAC of Instruction '74 and AAC of casualty per cent

\begin{tabular}{|c|c|c|c|c|c|c|}
\hline \multirow{3}{*}{$\mathrm{BH}$} & \multicolumn{6}{|c|}{$\mathrm{AAC}$} \\
\hline & \multicolumn{2}{|c|}{ '74 Instruction ** } & \multicolumn{2}{|c|}{ Casualty per cent } & \multicolumn{2}{|c|}{ The comparison $(\%)$} \\
\hline & $\begin{array}{c}\text { Area } \\
\left(\text { ha } \mathrm{yr}^{-1}\right)\end{array}$ & $\begin{array}{l}\text { Volume } \\
\left(\mathrm{m}^{3} \mathrm{yr}^{-1}\right)\end{array}$ & $\begin{array}{c}\text { Area } \\
\left(\text { ha } \mathrm{yr}^{-1}\right)\end{array}$ & $\begin{array}{l}\text { Volume } \\
\left(\mathrm{m}^{3} \mathrm{yr}^{-1}\right)\end{array}$ & $(4: 2)$ & $(5: 3)$ \\
\hline 1 & 2 & 3 & 4 & 5 & 6 & 7 \\
\hline Banyuurip & 66.20 & 8,253 & 44.58 & 5,538 & 67.3 & 66.4 \\
\hline Randublatung & 63.03 & 6,282 & 50.96 & 5,203 & 80.9 & 82.8 \\
\hline Ngliron & 73.43 & 10,143 & 53.23 & 7,558 & 72.5 & 74.5 \\
\hline Doplang & 52.74 & 4,475 & 21.58 & 1,980 & 40.9 & 44.2 \\
\hline Bekutuk & 54.50 & 6,810 & 38.40 & 4,793 & 70.5 & 70.4 \\
\hline Banglean & 59.76 & 8,645 & 44.90 & 6,578 & 75.1 & 76.1 \\
\hline Total FMU & 369.66 & 44,691 & 253.65 & 31,650 & 68.6 & 70.8 \\
\hline
\end{tabular}

** Source: Working Plan of Randublatung FMU, Planning Period of 2003-2012

'74 Instruction with Regulation Number P.60 in 2011 and Regulation No P.01/VI-BUHT/2012 does not change the method of AAC determination (Perhutani 2013).

The increase in population led to increasing pressure on forests and the pressure of population is likely a major driver of forest degradation (Widiaryanto 2012). During this time, various efforts to control forest damage has been done by PP with various programs of social approaches, but it does not achieve the results as expected (Setiahadi 2012). Thus the risk of forest damage is a necessity to be integrated in forest planning including the determination of the AAC.

The overestimates of AAC determination by $29 \%$ can be interpreted that the PP planned to harvest by $29 \%$ exceeding its increment. That is not true because the increment of $29 \%$ is to swap loss due to the forest destruction. At short impact, the $\mathrm{CPC}$ method may reduce the AAC. In the case of Randublatung FMU, the AAC determined using the CPC method results in approximately $29 \%$ smaller than the Burn method. It will impact on the company's revenue from the sale of timber, which currently contributes $55 \%$ to Perhutani's revenue from domestic sales (Perhutani 2011). However, in the longer time, the inclusion of this method will improve the standing stock of forest, and regulate yield more sustainably.

To implement the method of determining the AAC that considers the risk of forest damage with CPC approach, it is likely that PP could revise the Regulation of Director General of Forestry Utilization Number P.01/VI-BUHT/2012 on Technical Guidelines for Preparation of Working Plan of PP especially on AAC Determination chapter. Such changes must be followed by the preparation of software of the data processing system that has been made based on the '74 Instruction.

\section{Conclusion}

Teak plantations owned by PP, in various situationsincluding in secure condition, would have the risk of forest damage which could lead to the unproductive condition. The conventional AAC determination in PP has not considered the risks. Those methods should be evaluated by considering the risk of forest damage, so the overestimated of AAC value could be avoided. The rate of teak forest damage in PP with secure condition in the period of 1973-1992 accounted for approximately $0.8 \%$ per annum while after the period of 1993 it tended to rise up to $3.7 \%$ per annum. In an improved condition scenario, the result of AAC determination by considering the casualty per cent made up $70.8 \%$ compared to the result witout a casualty per cent. It could be said that there would be a overestimated condition of $29.2 \%$. In brief, the overestimated value had an impact on the growing stock decline.

\section{Acknowledgments}

We thank Perum Perhutani, especially the Bureau of Forest Planning in Salatiga, for permission to use the forest inventory data. We also thank Dwiko Budi Permadi of Faculty of Forestry Gadjah Mada University for valuable discussion about the yield regulation in the management of teak plantation in java. We appreciate the valuable comment and suggestions from anonymous reviewer that greatly improved the content of this manuscript.

\section{References}

Deten RV. 2011. Sustainability as a guideline for strategic planning? The problem of long-term forest management in the face of uncertainty. European Journal of Forest Research 130:451-465. http://dx.doi.org/10.1007/ s10342-010-0433-9.

Davis LS, Johnson KN, Bettinger PS, Howard TE. 2001. Forest Management: To Sustain Ecological, Economic, and Social Values. $4^{\text {th }}$ Ed. Boston: McGraw-Hill series in Forest resources.

Elbakidze M et al. 2013. Sustained yield forestry in Sweden and Russia: how does it correspond to sustainable forest management policy? AMBIO: A Journal of the Human Environment 42:160-173.

Hanewinkel M, Hummel S, Albreht A. 2011. Assessing 
natural hazards in forestry for risk management: A review. European Journal of Forest Research 130:329-351. http://dx.doi.org/10.1007/s10342-0100392-1.

Hardjosoediro S. 1974. Pengaturan Hasil Hutan Jati 1938 (Sebuah Interpretasi). Yogyakarta: Yayasan Pembina Fakultas Kehutanan UGM.

Ichwandi I, ShinoharaT, Chen B. 2009. Development of teak wood production and marketing in Cepu Forest District, Central Java, Indonesia. The Science Bulletin of the Faculty of Agriculture, University of the Ryukyus $56: 23-31$.

Luckert MK, Williamson T. 2005. Should sustained yield be part of sustainable forest management? Canadian Journal of Forest Research 35(2):356-364. http://dx. doi.org/10.1139/x04-172.

Leech JW. 2002. Allowing for risk in forward yield planning. Australian Forestry 65(4):232-236. http://dx. doi.org/10.1080/00049158.2002.10674875.

[MoF] Ministry of Forestry. 2008. Statistik Kehutanan Indonesia 2007. Jakarta: Ministry of Forestry.

[MoA] Ministry of Agriculture. 1974. Keputusan Direktur Jenderal Kehutanan No 143/KPTS/DJ/1974 tentang Peraturan Inventarisasi Hutan Jati dan Peraturan Penyusunan Rencana Pengaturan Kelestarian Hutan Khusus Kelas Perusahaan Tebang Habis Jati. Jakarta: Ministry of Agriculture.

Mon MS, Mizoue N, Htun NZ, Kajisa T, Yoshida S. 2012. Factors affecting deforestation and forest degradation in selectively logged production forest: A case study in Myanmar. Journal of Forest Ecology and Management 267:190-198. http://dx.doi.org/10.1016/j.foreco.2011. 11.036 .

Osmaston FC. 1968. The Management of Forest. London: George Allen and Unwin Ltd.

Perhutani. 2009. Kajian Kelestarian Potensi Sumber Daya Hutan KPH Randublatung. Salatiga: Seksi Perencanaan Hutan III Salatiga.

Perhutani. 2011. Statistik PP 2007-2011. Jakarta: Direksi Perum Perhutani.

Perhutani. 2013. Rencana Pengaturan Kelesarian Hutan
KPH Randublatung Jangka 2013-2022. Semarang: Biro Perencanaan SDH dan Pengembangan Usaha Perum Perhutani Unit I Jawa Tengah.

Recknagel AB. 1917. The Theory and Practice of Working Plans (Forest Organization). Second edition. New York: John Wiley \& Sons.

Rohman. 2008. Casualty per cent on AAC determination of teak forest plantation in Perum Perhutani. Jurnal Manajemen Hutan Tropika 16(2):55-61.

Seydack AHW et al. 1995. An unconventional approach to timber yield regulation for multi-aged, multispecies forests. II. Application to a South African forest. Journal of Forest Ecology and Management 77 (1-3):155-168. http://dx.doi.org/10.1016/0378-1127(95)03578-X.

Setiahadi R. 2012. Modal sosial dalam pembangunan hutan [dissertation]. Yogyakarta: Gadjah Mada University.

Simon H. 2001. Pengelolaan Hutan Bersama Rakyat: Teori dan Aplikasi pada Hutan Jati di Jawa. Yogyakarta: Bigraf Publising.

Simon H. 2010. Perencanaan Pembangunan Sumber Daya Hutan Jilid la Timber Management. Yogyakarta: Pustaka Pelajar.

Soeranggadjiwa MH. 1978. Penilaian Tentang Cara Penentuan Etat menurut Dienvoorchrift 1938 dan Kemungkinan Penyempurnaannya. Yogyakarta: Bagian Penerbitan Fakultas Kehutanan UGM.

Tiryana T, Satoshi T, Norihiko S. 2011. Modeling survival and destruction of teak plantations in Java, Indonesia. Journal of Forest Planning 16:35-44.

van Gardingen PR, Valle D, Thompson I. 2006. Evaluation of yield regulation options for primary forest in Tapajo's National Forest, Brazil. Journal of Forest Ecology and Management 231:184-195. http://dx.doi.org/10.1016/j. foreco.2006.05.047

Warsito SP. 2010. Metode Penyusunan Rencana Pengaturan Kelestarian Tegakan Hutan pada Skala Unit Pengusahaan Hutan Alam Produksi Berbasis IHMB. Yogyakarta: Diandra Primamitra Media.

Widiaryanto P. 2012. Does the pressure of population and poverty cause deforestation? Jurnal Ilmu Sosial dan Ilmu Politik16(1):84-93. 